\title{
Characterization of human umbilical cord mesenchymal stem cells-derived conditioned medium
}

\begin{abstract}
Medium where the stem cells are cultured is called conditioned medium (CM). In CM, Mesenchymal Stem Cells (MSCs) secrete different growth factors and cytokines with anti-inflammatory and anti-fibrotic effects. Numerous questions need to be answered before MSCs-derived CM can be used for the therapy of various diseases/conditions. The purpose of the present study is to analyze Human Umbilical Cord MSCs-derived $\mathrm{CM}$ for the presence of anti-inflammatory and regeneration-promoting cytokines. In our study of CM, immunoassay tests showed that all analyzed chemokines gave signals in the assays in positive control parallel wells. Thus all chemokines are functional and accurate to the indicated levels. Characterization of growth factors and cytokines in the MSCs-derived CM is crucial for further translation of CM in therapy of various diseases/conditions.
\end{abstract}

Keywords: cytokines, chemokines, human umbilical cord mesenchymal stem cells, conditioned medium
Volume I Issue 6 - 2016

\author{
Brian M Mehling,' Marine Manvelyan,' \\ Gabrielle Benesh,' Dong Cheng Wu' ${ }^{2,3}$ \\ 'Blue Horizon International, USA \\ ${ }^{2}$ Wuhan University, China \\ ${ }^{3}$ Department of Stem Cells, Wuhan Hongqiao Brain Hospital, \\ China
}

Correspondence: Marine Manvelyan, Clinical Research Scientist, Blue Horizon International, LLC, 2 I 4 State Street, Hackensack, New Jersey 0760I, USA, Tel (20I) 342 7662, Email mmanvelyan@bluehorizonhospital.com

Received: November 14, 2016 | Published: November 17, 2016

\section{Introduction}

Human umbilical cord mesenchymal stem cells (HUC-MSCs) are adult stem cells and a promising candidate for cell-based therapy. ${ }^{1}$ HUC-MSCs therapy has advantages over human bone marrow MSCs because collection of HUC-MSCs is an easier, less expensive, noninvasive or painful method and there are no ethical considerations. ${ }^{2,3}$ Medium where the stem cells are cultured is called conditioned medium (CM). In CM, MSCs secrete different growth factors and cytokines with anti-inflammatory and anti-fibrotic effects. ${ }^{4,5} \mathrm{CM}$ without the stem cells itself may cause tissue regeneration. ${ }^{6}$ Stem cells derived $\mathrm{CM}$, containing growth factors and cytokines, is a promising alternative that can overcome the poor engraftment of the transplanted stem cells and the potential risk of cancer development. ${ }^{7} \mathrm{CM}$ can be manufactured, freeze-dried, packaged, and transported more easily than stem cells. ${ }^{8}$ Numerous questions need to be answered before MSCs-derived CM can be used for the therapy of various diseases/ conditions. Analysis and characterization of cytokines and growth factors in $\mathrm{CM}$ is a very important step in the translation process of $\mathrm{CM}$ usage. The purpose of the present study is to analyze HUC-MSCs derived $\mathrm{CM}$ for the presence of anti-inflammatory and regenerationpromoting cytokines.

\section{Materials and methods}

\section{Preparation of UC-MSCs and isolation of MSCs from umbilical cord bloods}

Umbilical cord bloods were collected and MSCs were isolated from umbilical cord blood according to methods described by Mehling et al. ${ }^{9}$

\section{Preparation and culture of CM}

The supernatant was discarded and the cell pellet was re-suspended in the basic medium (GIBCO AIM V® Serum Free Medium). The cells were cultured in GIBCO AIM V ${ }^{\circledR}$ Serum Free Medium for 14 days at $37^{\circ} \mathrm{C}$. Fresh medium was added to the cultured cells every two days. After 14days of cell culture, the cells were harvested by centrifuge and supernatant medium was collected. The medium was filtered by $0.22 \mathrm{um}$ membrane. Germ test showed that the maximum of germs is limited for cosmetic products. Medium was frozen at $-80^{\circ} \mathrm{C}$.

\section{Cytokine immunoassay}

Bio-Plex Pro Human Chemokine 40-plex Panel was used to detect and characterize 40 chemokines. Cytokine Immunoassay was performed according to the manufacturer instructions (Bio-Plex Pro ${ }^{\mathrm{TM}}$ Human Chemokine Panel).

In order to characterize chemokines in $\mathrm{CM}$, the assays were done using two separate experiments, with each sample tested three times within each experiment. The control media was without conditioning

\section{Results}

Previous studies showed that CM have been tested in various kinds of diseases/conditions, including alopecia, acute and chronic hind limb ischemia, acute and chronic wound healing, spinal cord injury, lung injury and others. Application of $\mathrm{CM}$, containing various cytokines, showed improvement of these conditions. ${ }^{8,10}$

In our study of CM, immunoassay tests showed that all analyzed chemokines gave signals in the assays in positive control parallel wells. Thus all chemokines are functional and accurate to the indicated levels. Statistically significant difference was revealed between control group and CM (Table 1). Statistical analysis was done with the application of statistical software package Sigma Plot 12.0.

Different factors in $\mathrm{CM}$ act together to promote regeneration. Proinflammatory cytokines (for example IL-1 $\beta$, IL-6, and TNF- $\alpha$ ) are involved in the up-regulation of inflammatory reactions. 
Chemokines are functionally divided into two groups: 1) Homeostatic chemokines (for example CCL19, CCL20, CCL21, CCL25, CCL27, CXCL12, CXCL13) are responsible for basal leukocyte migration; 2) Inflammatory chemokines (for example: CCL2, CCL3, CCL11, CXCL10, CXCL1) are formed under pathological conditions and actively participate in the inflammatory response attracting immune cells to the site of inflammation.
Anti-inflammatory cytokines (for example: IL-1, IL-2, IL-10) are a series of immunoregulatory molecules that control the proinflammatory cytokine response. Stem cell derived CM therapy is a rapidly advancing field that promises to have a substantial impact on the treatment of different diseases/conditions. Therefore, gaining a more complete characterization of growth factors and cytokines in the MSCs-derived CM is crucial for further translation of CM in therapy of various diseases/conditions.

Table I Chemokine assay results

\begin{tabular}{|c|c|c|c|c|}
\hline Cytokine & Unit & Control Average \pm Standard error & Cm Average \pm Standard error & Statistical significance \\
\hline CCL2I & $\mathrm{Pg} / \mathrm{mL}$ & $30 \pm 12$ & $485.5 \pm 5.5$ & $Y E S, P=<0.001$ \\
\hline CXCLI3 & $\mathrm{Pg} / \mathrm{mL}$ & $18 \pm 0$ & $|7| .5 \pm 3.5$ & $Y E S, P=<0.00 I$ \\
\hline CCL27 & $\mathrm{Pg} / \mathrm{mL}$ & $15 \pm 3$ & $603.5 \pm 8.5$ & $Y E S, P=<0.001$ \\
\hline CXCL5 & $\mathrm{Pg} / \mathrm{mL}$ & $208.5 \pm 9.5$ & $7458.5 \pm 133.5$ & $Y E S, P=<0.001$ \\
\hline CCLII & $\mathrm{Pg} / \mathrm{mL}$ & $11.5 \pm 2.5$ & $101 \pm 4$ & $Y E S, P=<0.003$ \\
\hline CCL24 & $\mathrm{Pg} / \mathrm{mL}$ & $14.5 \pm 9.5$ & $332.5 \pm 7.5$ & YES, $P=<0.001$ \\
\hline CCL26 & $\mathrm{Pg} / \mathrm{mL}$ & $8.5 \pm 3.5$ & $61.5 \pm 3.5$ & YES, $P=0.009$ \\
\hline CCLI9 & $\mathrm{Pg} / \mathrm{mL}$ & $25 \pm 3$ & $73 \pm 9$ & $Y E S, P=0.037$ \\
\hline CX3CLI & $\mathrm{Pg} / \mathrm{mL}$ & $36.5 \pm 6.5$ & $749 \pm 17$ & $Y E S, P=<0.001$ \\
\hline CXCL6 & $\mathrm{Pg} / \mathrm{mL}$ & $36.5 \pm 1.5$ & $232 \pm 9$ & $Y E S, P=0.002$ \\
\hline GM-CSF & $\mathrm{Pg} / \mathrm{mL}$ & $26.5 \pm 2.5$ & $48 \pm 3$ & $Y E S, P=0.031$ \\
\hline CXCLI & $\mathrm{Pg} / \mathrm{mL}$ & $13 \pm 1$ & $85 \pm 3$ & $Y E S, P=0.002$ \\
\hline $\mathrm{CXCL2}$ & $\mathrm{pg} / \mathrm{mL}$ & $21.5 \pm 7.5$ & $503.5 \pm 11.5$ & $Y E S, P=<0.00 I$ \\
\hline IFN-gamma & $\mathrm{Pg} / \mathrm{mL}$ & $19.5 \pm 2.5$ & $50 \pm 2$ & YES, $P=0.011$ \\
\hline IL-Ib & $\mathrm{Pg} / \mathrm{mL}$ & $8.5 \pm 3.5$ & $78 \pm 5$ & $Y E S, P=0.008$ \\
\hline IL-2 & $\mathrm{pg} / \mathrm{mL}$ & $2.5 \pm 0.5$ & $15 \pm 1$ & $Y E S, P=0.008$ \\
\hline IL-4 & $\mathrm{Pg} / \mathrm{mL}$ & $4.5 \pm 0.5$ & $222 \pm 3$ & YES, $P=<0.001$ \\
\hline IL-6 & $\mathrm{Pg} / \mathrm{mL}$ & $25.5 \pm 3.5$ & $45 \pm 3$ & $N O *, P=0.052$ \\
\hline IL-8 & $\mathrm{Pg} / \mathrm{mL}$ & $10.5 \pm 2.5$ & $60.5 \pm 2.5$ & YES, $P=0.005$ \\
\hline IL-10 & $\mathrm{Pg} / \mathrm{mL}$ & $36 \pm 16$ & $180.5 \pm 4.5$ & $Y E S, P=0.013$ \\
\hline IL-16 & $\mathrm{pg} / \mathrm{mL}$ & $26.5 \pm 1.5$ & $333.5 \pm 8.5$ & $Y E S, P=<0.00 I$ \\
\hline CXCLIO & $\mathrm{Pg} / \mathrm{mL}$ & $11 \pm 1$ & $170 \pm 1$ & $Y E S, P=<0.00 I$ \\
\hline CXCLII & $\mathrm{Pg} / \mathrm{mL}$ & $15.5 \pm 0.5$ & $184 \pm 4$ & $Y E S, P=<0.00 I$ \\
\hline $\mathrm{CCL} 2$ & $\mathrm{Pg} / \mathrm{mL}$ & $19 \pm 0$ & $211.5 \pm 6.5$ & $Y E S, P=<0.00 I$ \\
\hline CCL8 & $\mathrm{Pg} / \mathrm{mL}$ & $1.5 \pm 1.5$ & $39 \pm 3$ & $Y E S, P=0.008$ \\
\hline CCL7 & $\mathrm{Pg} / \mathrm{mL}$ & $2.5 \pm 0.5$ & $15 \pm 3$ & $N O *, P=0.054$ \\
\hline CCLI3 & $\mathrm{pg} / \mathrm{mL}$ & $0.5 \pm 0.5$ & $14.5 \pm 0.5$ & $Y E S, P=<0.00 I$ \\
\hline CCL22 & $\mathrm{Pg} / \mathrm{mL}$ & $44.5 \pm 3.5$ & $533 \pm 9$ & YES, $P=<0.00 I$ \\
\hline MIF & $\mathrm{Pg} / \mathrm{mL}$ & $13.5 \pm 1.5$ & $167 \pm 6$ & $Y E S, P=0.002$ \\
\hline CXCL9 & $\mathrm{Pg} / \mathrm{mL}$ & $11 \pm 1$ & $|5| \pm 3$ & YES, $P=<0.00 I$ \\
\hline CCL3 & $\mathrm{Pg} / \mathrm{mL}$ & $7 \pm 1$ & $33.5 \pm 1.5$ & $Y E S, P=<0.001$ \\
\hline CCLI5 & $\mathrm{Pg} / \mathrm{mL}$ & $1.5 \pm 0.5$ & $I I \pm 1$ & $Y E S, P=0.014$ \\
\hline CCL20 & $\mathrm{Pg} / \mathrm{mL}$ & $3 \pm 0$ & $12 \pm 2$ & $Y E S, P=0.046$ \\
\hline CCLI9 & $\mathrm{Pg} / \mathrm{mL}$ & $18 \pm 3$ & $154 \pm 4$ & $Y E S, P=<0.001$ \\
\hline $\mathrm{CCL} 23$ & $\mathrm{Pg} / \mathrm{mL}$ & $2 \pm 2$ & $37.5 \pm 3.5$ & $Y E S, P=0.013$ \\
\hline
\end{tabular}


Table Continued..

\begin{tabular}{lllll}
\hline Cytokine & Unit & Control Average \pm Standard error & Cm Average \pm Standard error & Statistical significance \\
\hline $\mathrm{CXCLI6}$ & $\mathrm{pg} / \mathrm{mL}$ & $34 \pm 4$ & $1205 \pm 25$ & $\mathrm{YES}, \mathrm{P}=<0.00 \mathrm{I}$ \\
$\mathrm{CXC12}$ & $\mathrm{pg} / \mathrm{mL}$ & $59 \pm 3$ & $1861 \pm 14$ & $\mathrm{YES}, \mathrm{P}=<0.00 \mathrm{I}$ \\
$\mathrm{CCLI7}$ & $\mathrm{pg} / \mathrm{mL}$ & $10.5 \pm 1.5$ & $124 \pm 4$ & $\mathrm{YES}, \mathrm{P}=<0.00 \mathrm{I}$ \\
$\mathrm{CCL} 25$ & $\mathrm{pg} / \mathrm{mL}$ & $80.5 \pm 11.5$ & $1911 \pm 29$ & $\mathrm{YES}, \mathrm{P}=<0.001$ \\
TNF-alpha & $\mathrm{Pg} / \mathrm{mL}$ & $8.5 \pm 3.5$ & $52 \pm 8$ & $\mathrm{YES}, \mathrm{P}=0.038$ \\
\hline
\end{tabular}

*The calculated $\mathrm{P}$ is not much higher than $\mathrm{P}=0.05$

\section{Acknowledgements}

None.

\section{Conflict of interest}

The author declares no conflict of interest.

\section{References}

1. Li T, Xia M, Gao Y, et al. Human umbilical cord mesenchymal stem cells:an overview of their potential in cell-based therapy. Expert Opin Biol Ther. 2015;15(9):1293-1306.

2. Wu LF, Wang NN, Liu YS, et al. Differentiation of Wharton's jelly primitive stromal cells into insulin-producing cells in comparison with bone marrow mesenchymal stem cells. Tissue eng Part A. 2009;15(10):28652873.

3. Divya MS, Roshin GE, Divya TS, et al. Umbilical cord blood-derived mesenchymal stem cells consist of a unique population of progenitors co-expressing mesenchymal stem cell and neuronal markers capable of instantaneous neuronal differentiation. Stem Cell Res Ther. 2012;3(6):57.
4. Baksh D, Yao R, Tuan RS. Comparison of proliferative and multilineage differentiation potential of human mesenchymal stem cells derived from umbilical cord and bone marrow. Stem Cells. 2007;25(6):1384-1392.

5. Akram KM, Samad S, Spiteri M, et al. Mesenchymal stem cell therapy and lung diseases. Adv Biochem Eng Biotechnol. 2013;130:105-129.

6. Kim HO, Choi S. Mesenchymal stem cell-derived secretome and microvesicles as a cell-free therapeutics for neurodegenerative disorders. Tissue Engineering and Regenerative Medicine. 2013;10(3):93-101.

7. Bhang SH, Lee S, Shin JY, et al. Efficacious and clinically relevant conditioned medium of human adipose-derived stem cells for therapeutic angiogenesis. Mol Ther. 2014;22(4):862-872.

8. Pawitan JA. Prospect of stem cell conditioned medium in regenerative medicine. Hindawi Publishing Corporation. BioMed Research International. 2014;2014:1-14.

9. Mehling BM, Quartararo L, Manvelyan M, et al. Safety study of intravenously administered human. Cord Blood Stem Cells in the Treatment of Symptoms Related to Chronic Inflammation Cell. 2015;3(2):e1562.

10. Jayaraman P, Nathan P, Vasanthan P, et al. Stem cells conditioned medium: a new approach to skin wound healing management. Cell Biol Int. 2013;37(10):1122-1128 